\title{
Novel Vector based Forwarding Protocol and Efficient Depth based Routing Protocol Acoustic Underwater Wireless Sensor
}

R. Thiagarajan ( $\nabla$ rthiagarajan.phd@gmail.com )

Prathyusha Engineering College

\section{Balajivijayan}

Vignans

R. Krishnamoorthy

Sree Sastha Institute of Engineering and Technology

I. Mohan

Prathyusha Engineering College

Keywords:

Posted Date: March 19th, 2021

DOl: https://doi.org/10.21203/rs.3.rs-312620/v1

License: (c) (1) This work is licensed under a Creative Commons Attribution 4.0 International License.

Read Full License 


\section{Abstract}

The authors have requested that this preprint be removed from Research Square. 